\title{
化㗨物質的中文命名問題
}

陶坤

\section{一 引言}

中國有一些語言學家對於中國化學物質 (元 素和化合物)的命名問題，一直非常關搞，他們不 斷地提示了許多珤貴的意見。大概是由於化學工. 作者與語言學家少有接䚪的緗故，這些意胃長期 存在着,一直汥有䋑過討論,實在可喈。

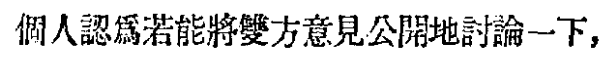
使語言學家進一步地協助化學工作者來整訂中文 化學物質名詞，䈏能使中國化學物啠命名工作人 大地提高一步，對於中國化學的普及與發展亦必 更捔裨㖉。

一储化學名詞工作者對於這些意見，確賽是 特别烈疆。因此，㑬人很想提出一些能供同志們參 浮的意見。但是由於對語言學的無知和化學知識

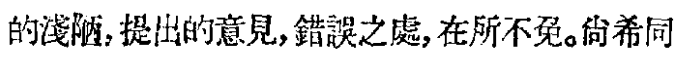
志們尤其是語言學界的同志們多多指正。

本交擬先特圆際及中国化學物質命名方法約 略介緑一下，同時討諭語言學家對中文命名的一 些意見。然後再討論能不能企部音譯和國際化的 問題, 最後赫一下今後中交命名發展的方向。

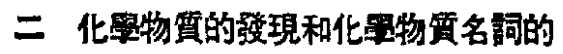 出現}

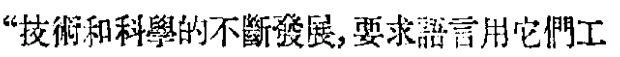

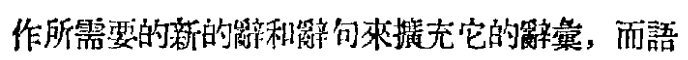
言直接反應這程需要，它就用新融來充實自己的

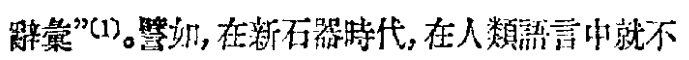
會有“銅”這縻一储名部出現, 决不會们人燱想天

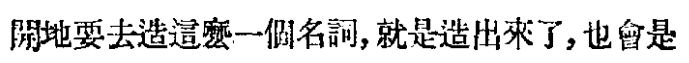

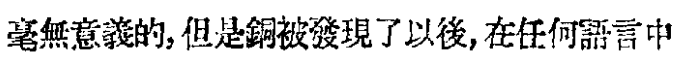

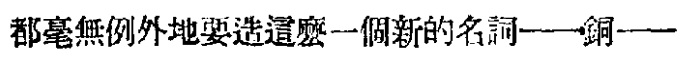

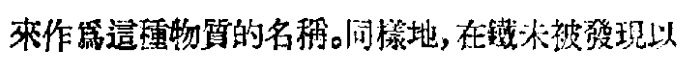

前, 不會有“鐵”道個名詞, 但是到了鐵被發現以 後, 就必然要有“鐵”這息一润名稆了。

近數世紀以來，隨着化學物質的大量墢現，在 各國語坛中就都琶整例外地汿現了大批的新的化 學物質名詞。這是化學發展對語言的要求, 也是語 言發展的正確道路。

\section{三 化淟物算名詞的系統化}

化學物筫 (元素和化合物) 的數目非常繁多, 迄今已墢現的大約在一百萬種右右, 而且数目遝 在日盆檑为着。所以它們的命名是一件非常困難 的工作，它們的名稃必須要有啝整的系統才能够 記憶和學碓。

在舆期摸索和發展中，化學物質名詞的系統

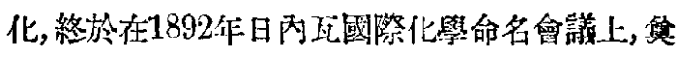
定了根基。這程系統命名的主要精神是在於將化 學物質的基本(構)成(部)份一元素, 重要官能 團, 主要需體化合物一一各取一倜名稃。然後循此

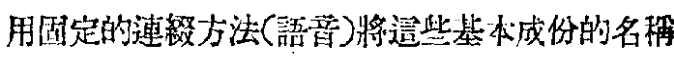

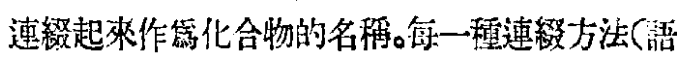

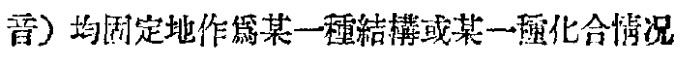
的代表。

化學基本成份, 數目較詿化學物質要少得多, 它們为多種結合的方法形成了各琵各樣的化學物 質,亚且由此規定了各理化學物質的特性。化學基 本成份黄泛而文㠅地出現在化學物質之中，所以

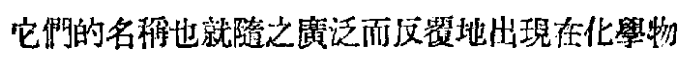
質的名詞中，亚且它們在名棓中依靠固定的連経 方法代表了化學物質的結構，同特也就指明了物 筫的特性。基本成份的名稆成篇了化學物軹名詞 的基本詞镜，而一般化學物質的名稱就成了基本 詞诨的複合詞整。化學基本成份不多而組成的化 學物質很多, 所以化學基本詞梏也不多, 而其複合 
詞营却非常之多，易烸吾先生說: “現在人造了氮、 氧、氮等字……若殞這栐做法, 一字一詞, 北京人

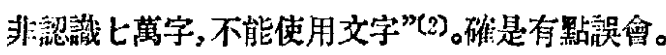
中國化學新字不是這粶造法的，是用很少的字稀 成千百萬㑭詞的。

\section{四惜用常用字的湿淆和造字的必要}

化覜基本詞荤是不是可以借用常用字造詞而 不另造新字呢?能不能用“白金”“䅂氣”等名詞來 作傜元素的名程呢?

至今還沒有一種語言這粶做法。化學基本詞

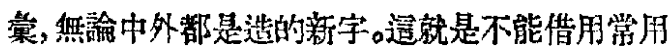
字造詞和必要造宇的钱證。

英文中不能把攻元素程做 green gas，greengas, greenish yellow, 或 green 而借用希聯字 源，造了一個新字 chlorine. 就是因篇借用常用

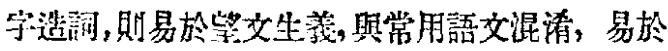
南生不必要的誤會, 所以不能借用。同樣地, 氢元 素在英交中不能叫做 waterbearing 而叫做 hydroyen; 如此㝵化莖( hydrogen clloride) 得不被誤 會成“維化生水” (waterbearing greenide) 然而中

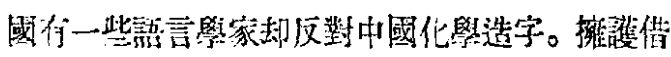
用常用字造詞。反對“氮”、“鎮”等等化學新字的

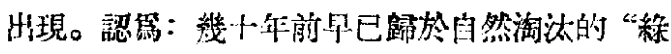
氣”、“白金”翻得好。因筬“字形本常, 容易認得,

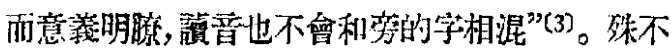
知字形平常則易祭掌用語文相混，而其所謂的“意

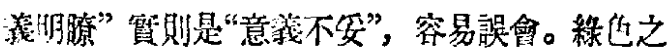

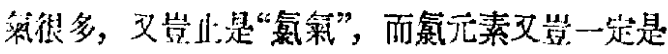

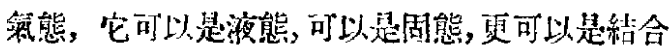
狀態。單把“氮点”利“線氣”、“鉑素”和“白金”比

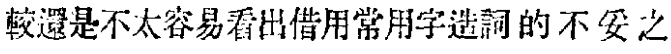

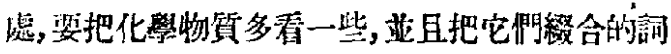
比较一下, 就可以更明白了。警如 “白金”會同商 業.上一種常用的合金 white gold 相混。在化學複 合詞中,“固態㮀策”、“稆氣化輕氣”、“綵氣酸”、

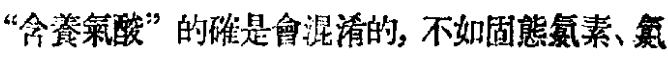
化氧、氛酸和合柔酸镜單明膫。

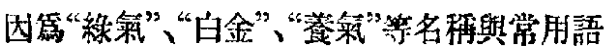
文湿添, 容易誤會, 非改不可,但是已經譯了一些時 侯，所以常時的中國化學家就取了其第一音節而 造成新字“氮”、“銆”、“氧” 作第這些元素的名稱。
漢字同音字大都用形解來分别，所以用了造麼些

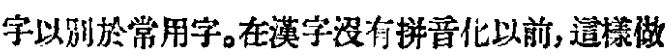

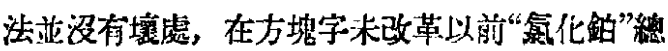
比“緗化白”要好一些。在读字汥有拼晋化以前,在

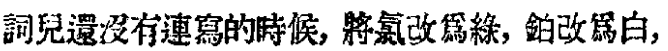
氧改第秦是不好的。

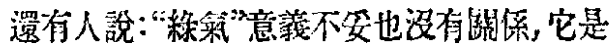
一倜不可分開的詞，恰像西藏的“紅花”不會被郒

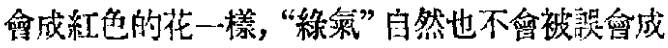

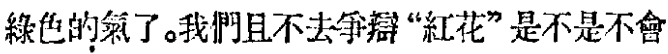

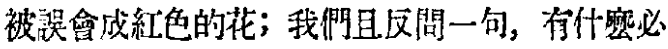
要去探用這些欠要的名詞呢? 有什㦄必要柬造成

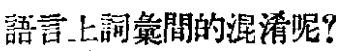

化學基本成份造些字來代表是將化學物筫名 詞系統化的唯一方法, 捨此, 别然其他途徑。造宇 是必要的，所以無論中外才都造了些化學新宇。在 中文中，迄今不過造了一兩百估化學新字，但是已 經解决了成千累萬储化學物筫的名稱，這一點似 乎有些棓言罢家一道都不了解。

\section{五 增加了同晋字的问題}

增加了一個化學新字就始加了一㮯同普漠 字, 有些同志認第這是一倜很戰重的問題。筫则 不然。中國的同音字向束多得很，然而一則少存骂 用，多櫂合成不同的詞來用;二則同音字的字義不 同，應用的範路不同; 三则宇的形象有别,所以中

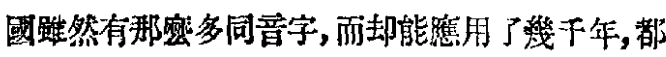

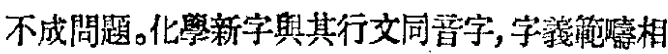
差更遠, 而文少有單用(見本交第八節), 所以更不 會成第問題。

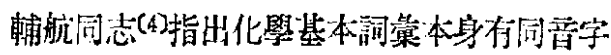

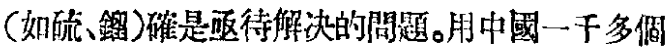

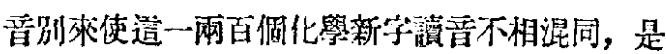
完全可能的事。希望棓言學界同志整助化學界同 志一同來解决邆倜題間。

\section{六 增加了婹字負塔的問題}

有許多同志㴔焦化學新字不容易認得, 化學 界也想造一些容易認得的字。在化悬命名原則的 第一篇定名總则中，就規定所取的字要便於兴晋。 化學家常常用字根(晋符)和偏傍隶解决認字的负

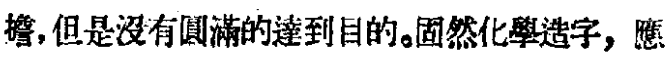


更進一步與語需學家聯熬，嘴量造一些容易認得 的字。另一方面也希望同志們費一點工夫認一認 這些化學新字。因第就是十分簡單而又常用的人、 |1、日、月等漢字也和它們的音之間沒有什㮣聯 奖。它們在當初也都是新字, 在今天也還是要—— 地去認，才証得的。人、山、日、月，是常見的事物， 造戠倠新字是必要的，化點工夫去認它們，也是

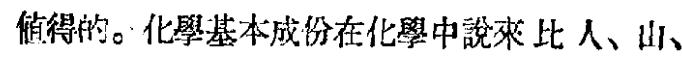
日，月，更篇常見，粪些字更是必要的，化些 工夹去認，更是优得的。認化學新字踓然是一種 保操，但是却是一项值得解据的貿售。認漢字的 闲難㑇决了，認化學新字的困蜼:也就隨之㕟解决 了。

化學基本成分的名稃原则上，僅僅是规定一

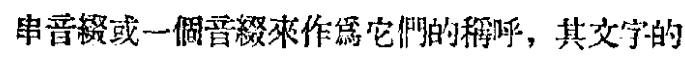
形象或會意方面是次要的問题。鄭昼文先生老早 就砏過; “取其可篇……標徽足㚐。……不宣徒事. 形體之末”(5)。化學命名原則也規定取字不重象 形。中國化學新字會運用了中國漢字便利之處。但 决不拘泥或局限於中國的漢字。有人以篇中四化 祭物質名詞的系統性是建筑在漢字基礎之上的, 也是誤會。

\section{七 化學基本詞集昔莭短少的便利}

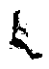

在上面第二節，我們已經討諭過，化學基本成

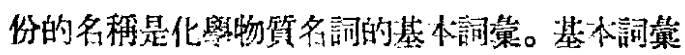

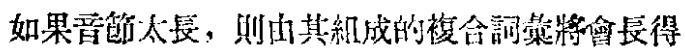
不能應用了。在多至綴的西洋語文中，化學基本詞

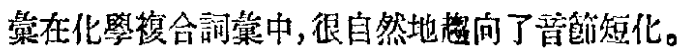
例如aldehyde 短化成了-al (䤑); alcohol及 phenol 短化成了一l (醇及酚)。-one(䤅), - ane (烷), - ene

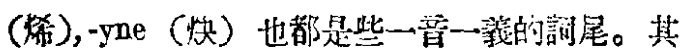
他基本詞黄在経合時略去若干音節则更是常見的 事。

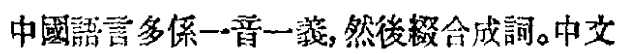

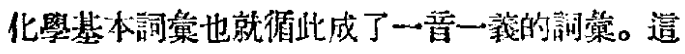
在化學命名上准很大的便利, 使化學物買名詞得 以簡短。它們都已造了很久, 一般人旅要在最近 二十年丙蓝過化學一課者, 大都均已熟潘。所以 已造的單曋詞靠似乎不必再改成複音, 以免增加 混筬。

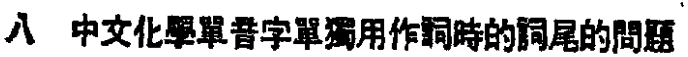

周趡人先生說: “在講話的時，音多則易分

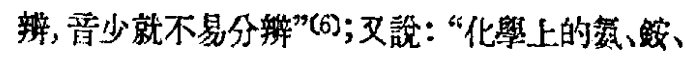

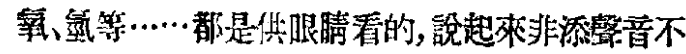
可, 否則聽不清楚”( 万。有些語言學家也有着同樣 的意見。這些意見對化學單吾字單猲用作名詞時 來說, 確是對的。這些單音字在單罚用作名稳時, 是應當加詞尾的。在應脷時,有些同志也就正確地

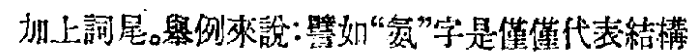
篇 $\mathrm{NH}_{3}$ 的物質，而不論其狀態的。若指此程化合物

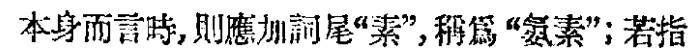
其氣態而言時,則隼为詞尾“氮”，呼篇“氮氣”; 指其

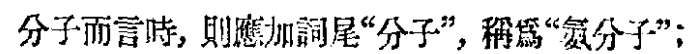
指其基名 $-\mathrm{NH}_{2}$ 而言㭙, 則隹加詞星“基”，稱篇“炎 基”; 若指其水溶液而言，則焦加詞尾“水”，称篇

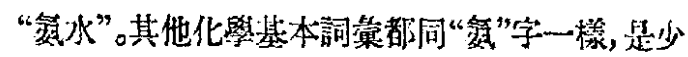

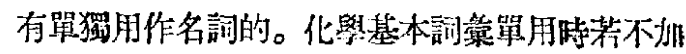

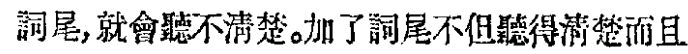
又意義明碓。

一般說來元素名稃單獨用來指元素本第而言

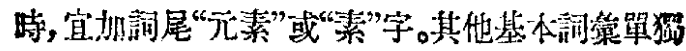
用時可勘酸規定加基、根、素、犋、精、族化合物… …等等詞尾。化學:基本詞鯷單用時的詞星宜速予 規定。語䛨學家的賽出意見是應當重視的。

\section{九 化合物的俗名}

根據化合物分子內部組成結構而取的名程时 做化合物的系統名棌, 上面所說的大都是系統名 程的問題。有些化學物質除了系統名稃之外還有 俗名, 俗名是不根據化合物分子內部的組成結構 來取的名稳。

俗名的产生是出於(一)常其少發現時，結棰

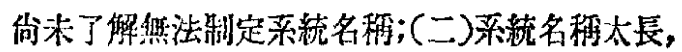

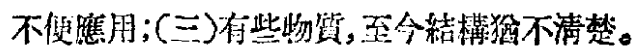

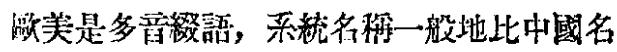
稱長，系統名因等太長而不便㗹用的就比中國較 多,所以俗名的需要量就比中國大。标以歐美化學 物筫的俗名多金是在摸索中绸别整訂的。當佣登 現時往往卜分简單的物質，也汥有了解到它的結 構，也就訂了些俗名，蕜且每每就沿用了下來。由 此可知，部多化合物的㗂美俗名在中文中是不必 
要的。

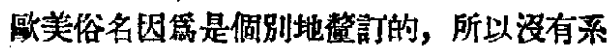
統。而它們又可以說是毫無例外地都是每倜名詞 一假新字，造些新字又都是借用乔脰或拉丁字源 東創造的。所以非推究字源不能知其㴬義, 非死背 不能記境。尤其是對於我們中國人來梳、我們的語

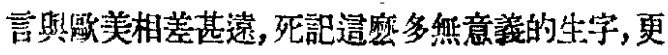
是困難。

在化合物已經發現了不少的今天，我門來教 訂化學物質的中文俗名，的確有很大便完。系統名 程不長的化合物，我們就不必再訂俗名，系統名栲 太長或牦系統名稳可用的化合物，我們則可以分 類地系緿地來訂俗名。除了妳少数重要的類名如

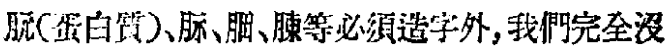
有籍倜名詞造一储字的必要。生物化學名詞草案 中所列的中文俗名已經比哂文俗名系綂得多，若 能根㨜該项草案再予整理一番, 必然更呚整有條, 易枋易訩了。

\section{+ 조部書譯的問題}

化罗物筫名詞是不是可以圣部吾譯呢? 在清

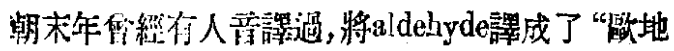

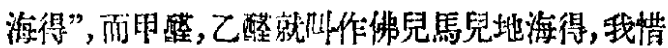
他兒地海得等等了! 這種曋譯的方法像是花一䇥,

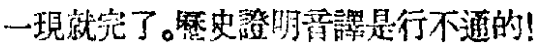

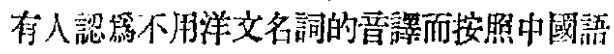

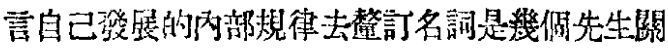

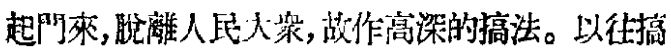

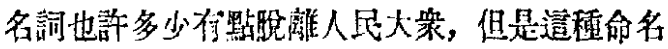

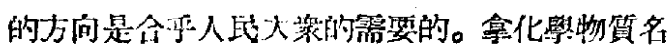
詞來說，在以往入學校裹一般是用洋文的。䑣酸

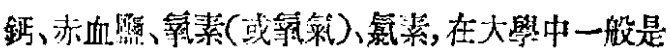
不肚中文的，但是中學生和一般人民大臬都用這 些中文名稳。䠰管以往本殖民地的中國，英-文那樣 被推崇和流行, 留篮高极知識份子要用洋文, 而中

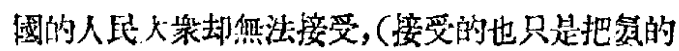
水溶液叫阿莫尼亞，幾倜音譯名葐)。如果，那個時

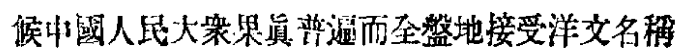
或其番譯，那密以往和今天都不會有人硬要再去 訂一奉中文名稃，秝對沒有人反對全部音譯。

可是事賽不然，歴史提供了鐵的事資，證明化 興物翼洋文名稃及其音譯是中國人民大臬所不要
的果西。有些同志還不信服，硬要提倡。茲特將化 學物質名詞不能全部㡍㩐的理由提出，請大家指 正。 憶。

第一、音譯的名稱不系統，人民大采不能記

曹伯韓先生說：音臎可以保存原文的 “眞 相”(3)。事實不然。昔譯是不能保存原文的“真相” 的。原來来統的名棌,一經音譯, 就會走了樣。䇾如 othane, ethyl是斯然有關係的名詞; 但是譯起來就 成了“愛染”和“涭醉兒”，美之甚遠了! Ethoxy 很 镍然是ethyl+0xy。中文譯起來就成了“要嫂克西” 看不出是“愛染兒”加“解克西”了。

原來系統的名棌, 普譯起來唒且如此不系統, 那稫原來就不系統的西文俗名，又如何了得呢? 精 通外交的先生椚，大概未見得也都精通了希脸、拉 丁文，精通了乔臘、拉丁文也不能僻决記憶困難的 問題。說一僻“雷畬辛”，纷可知其何謂也!䛦些倜 “阿爾金塞” (arginine) “來落頭弗來聞” (lactoflavin) “錴針弗來期” (riboflavin)，格拉已俄克 西利克阿西得 (glyoxylic acid) ……如何揣得清 楚呢?

英文名稃如果果㫐十全十美, 要求達到保存 “貪相”還有得可說, 這榡不系統, 不科學的英文俗 名。文有什㮣“真相”值得保存呢? 再者, 如其說是: 音譯會保存原文的“葚相”, 不如說是:音譯能保存 原文的“生疏面目”。因而西洋原文對中國人民是 生疏的。

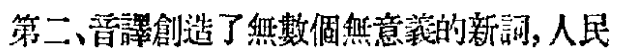
大尊, 嘫從記憶。

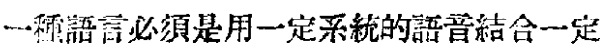
系統的意淁才能婊涬思想的。何種語谙代表何種 意義在當初是一個社會任意規定的。語音和意義 之間，在米約定之先是沼有紹對固定的聯慗的，但 是一經約定之後，便就有了相對的固定的聯獒了。 中國是單至綴語，每一㑑語音是固定地代表浇種 意義的。他們又系統地配合成了複暗的詞; 在詞中

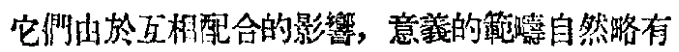
轉變。單音的字所代表的不同的意㜔是不會相混

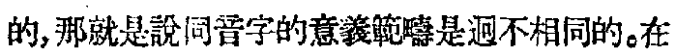

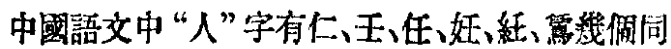
吾字，那就是馀：日广這佩語音在中國語文中有

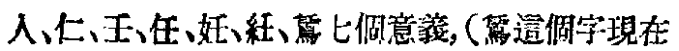


不大常用, 用時也得加上一個鳥字), 道狨做字的

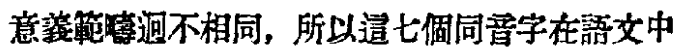
不會相混。其他的同畐字也是這溙的。語昔與意義 之間有着相對的居定的聯繫是語言的系粺性，不

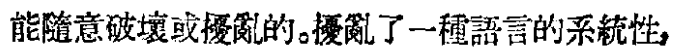
則這種語言將不能作罿傳㑢思想的工具, 同時也 不能作筑思維的工具了!

昔譯的化學物霓名詞與中國全民語言沒有關 係。它們本身沼柱系統而又不具有中國語言固有

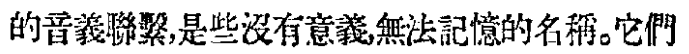

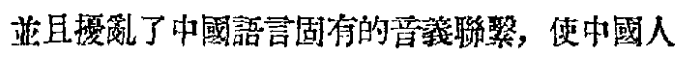
民大㖣很可能邀循中國語音固有的意義從而㡾生 一些不必要的誤會。外交學得很好, 而化學又學得 不錯的人，假如他又對於外文字嘼、字尾、字根、字

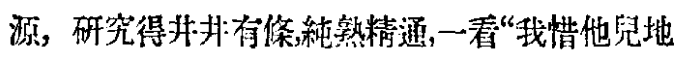
海得”也許可以知道是代表什鷹東西。但是這㻬人 似乎不多。大多數人朁不太精通外文，對於化學也 未見得都是専門，一看“我惜他兒地海得”, 就然法 了解了。一储短短的洋文音譯如此費解，上百萬個 比這繁雜得多的化學新詞如何記憶, 從何學習呢?

一下詯是六僻音譯的化學物睤名詞

1.哈已笑若克羅里克阿唒德

2.波塔酒姆斐里沙已安那已德

3. 墨耳耶里巴已克䓔造特

4.索第厄姆葆爾裴特

5.達已克羅若厄焬爾蘇爾法已德

6. 特特刺垶惕雨阿莫尼姆哈已竺落克莎已德

它們是相罍簡單的物筫，它們的英文名稃並 不太舆, 可是其晋譯的中文名詞则就“隔日即不能 自揃, 雨人即難期共曉”了!

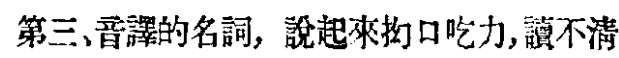
楚。

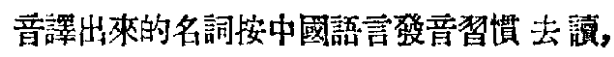
去原來洋支的發曋很遠, 份且那些字在中國語言 柏慣上是不連用的，所以中國人讀起來非常抣口

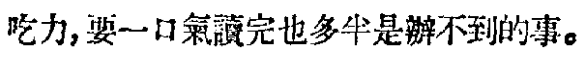

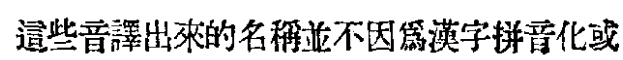
竟拉丁化而就能成篇好記好渻的名詞，因第漢字 改革, 亚不改革中国的語言。漢字不論如何改革, 音譯的名称還是要照上面的公阎例子去讀，還是 一椂的要不得。若是拉丁化的漢字昔譯名詞果莲

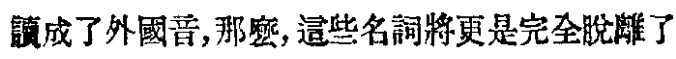

中國的全民語，中國人民更是不能記憶和學習了。 第四、曋臎的名詞不合於中國的構詞方法。

中西構詞方法不同是衆所週知的事。在化學 物質名詞中，英交常常用字尾的變化來椿詞。例 如：chloride, sulfuric acid 中的-ide 及-ic 便是。 或用母吾的改變和刖去不重要的詞星等方法來構 詞, 例如 chloro-benzene 中的 chlorine 将-ine 改 成 -0 便是。這些不同之處多得很, 不朌份舉。去掉 或改變了這些西交構詞方法, 就失去了当譊的意 淁(要國際化)。而這些西文溝詞方法却是中國人 民大奌記譩, 了解和學習上莫大的困難。

總括起來說, 化學物質名濐全部音譯起來就 成了一些難讀、難到、無法學習的“呪語”。人民大

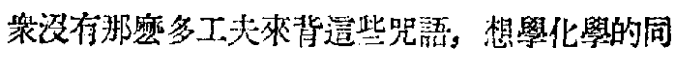

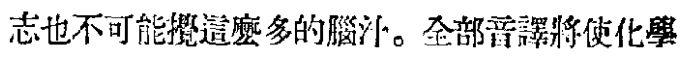

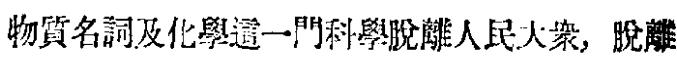
全體中國人民，而中國學化學的少數專家别乾璄 用外國書, 講外國話, 而不會把 hydrochloric acid 念成什“哈已然羅……”。到了這璉地步，纷復何 言!同溙地, 其他科學名詞全部㩖譯起來地就成了 記不清的呪語。科學名詞記都部不消, 科學又從何 學起。型到中國人民船從學科學，豈不大大地氹背 了主張科學名荡全部音譯的生生們的“初東”磨?

化學物質名詞統一工作的目的是在於訂出簡 明系統的中文名稳，以便於中國人民學㫘化學。音 譯達不玨這個目的。它底而堌加了學習化學的困 難。而全部吾譯則使中國人民热法學化學了。所以

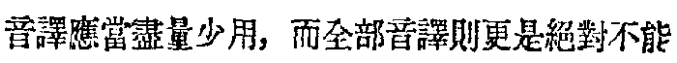
用!

\section{十一聚術名詞國際化的問題}

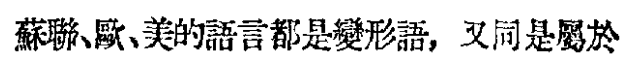
印度歐羅巴語族的語言。語言系統相似，所以它們 的學街名詞可以互相探用，因而就這機同語言來 說, 其學術名詞是相當國際化的。龙其是它临的化 學物貎名詞都是從希臘、拉丁字源來造的字，所以 更是相賞統一。中國語言則與它們不同, 是單音経 語, 語言系統同它們美得很遠。所以它們的學術

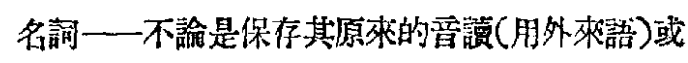

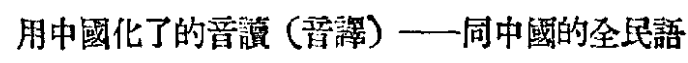
言是毫無關係的。它們殷不符於中國語言固准的 吾俄聯繁, 又不合於中國語言的發晋習慣, 更不 
容於中國的構詞規則。所以它們對中國人民說來

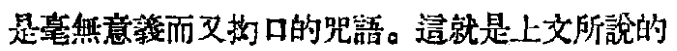

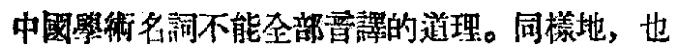
就是中國學街名詞不能全部探用外來詰的道理。 外國名詞也有竍多訂得不好，因此，中國的學衔名

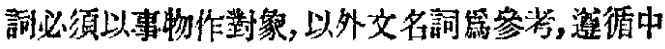
国語言自己發展的內部規律來穜訂。中國學街名 詞的㓍一工作是中國吸收、普及和發展學術的基 本工作。

有些同志不明白這個道理，認営中國的舉術 名詞遵循中國語言自己發展的內部規律來鳌訂就

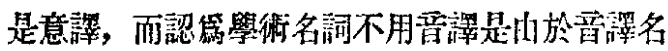

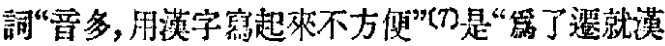
宇系效”(8)的矮故，把問題不從中國語言体身去考

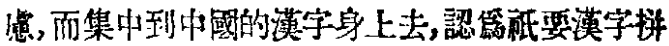
晋化了，最好是拉丁化了，那麼中國語言就可以企 部吸收外來的學術名詞了。說是 “Dichloroethyl-

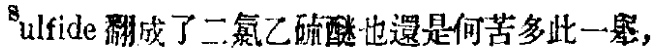
若是改用拼亩字，譯菨的字可以诚少，更無所謂 譯吾”(9)丁!

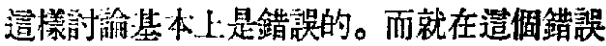
的基礎. $\mathrm{E}$ ，周:生了許許多多的意見。這些意見總

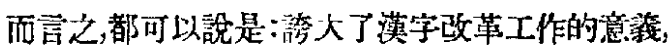

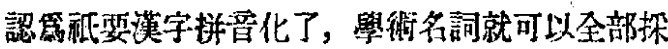
用外來部了。到那㭙候將把“原子、鎮、既等一律恢 復其本來面目第 atom, uranium, radium等"(10)了。 “Mator, sofa, pump, radio, model 等可以照原樣搬 過束，如 polish，meter, gram等畵可以照中文垬吾， stick, moderu, pass 㷳唼改成 stik, moden, pas"(10) 了! “(化學俒素)英交名稃和拉丁名稳完相同的,

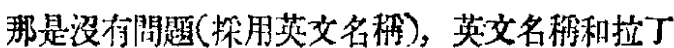
名稱根幹不同的，探用拉丁名䅎”(4)（圆括弧內的 字是作者按原文之意加上的), 就把“monogenic 譯 做 monogend"(11)“differential 在這時候難道還有 理由强迫人家來認識一個“微分””(11)应?……等等 學衙名詞(甚或非學衔名詞) 國際化的意見。

於是乎N.Xs同志就“大胆提出 ‘中國語言，國

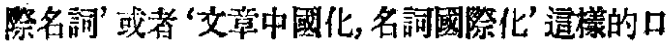

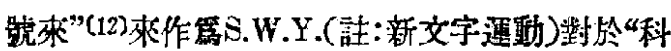
學應該用什㮣文字寫”一事，長期討諭的“短論”中 的結論: 而 Mroman先生 (13)也就遵循了此項號召， 特化學物質名詞按英交字形稍予改動，或不予改

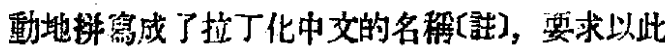
程名稃桃代替現在通行的中文化學物筫名稃。

䢜種“交竟中國化，名詞國際化”的語言，若將 外來字警外國畐就成了：“Dichloroethylsulfide, 是 一種 organic compound, 其中含有 chlorine element, 不含 ox gen element。”不中不西。若將外来

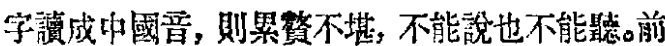
一㜔法是在解放前大學講堂中管經存在而今日已

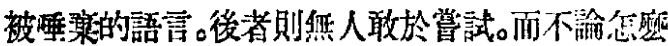

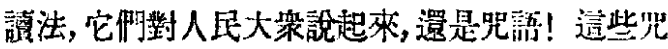
語組成的句子和文章是不能作篇人民大葲傳澾思 想的工具的。歷史證明，它們社能在往昔的大學蚉 堂中一度存在而不能走向民間，歴史也證明它們 今日將成第一去不返的東西!

主張中國“學術名詞國際化”闰志們的目的， 是盛了便於中國與國㻮間學㑹的交流。但是如果

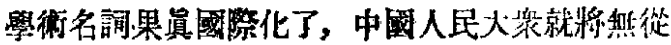
學翼學術; 於是學衔在中國就“流”通不起來, 更 談不上去和外國交“流”。這恰恰是妨察了中國與 國際間學衐的交流，違背了主張“學術名詞四際 化”同志們的目的。手段與目的相造背，是多瓷代 智之舉呢!

中國語言與西洋迥巽，學術還是一这在交流

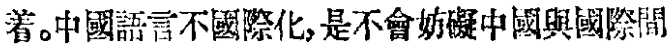

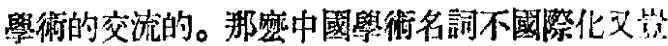
會彷凝中國與國際間學術的交流呢?

再說，學術名詞大衆化是中國學術普及和設 展的前提，而中國學衔的普及和發鼠則文是中國 學街與國際間學術交流的前提。逢循中國湋言内

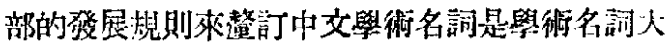
登化的道路, 因而也就是發展中國學衡, 促進中四或

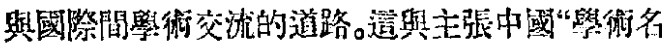
詞國際化”同志們的目的完奎一致, 而也正是達到 此目的底唯一道路!

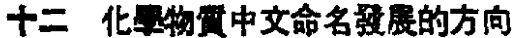

“語嘼是思想的遖接現赛”(傌克思），是思想所 化賴的工具。語言工具本身的侵劣對於思想的發 渎有着道接的影響。化學物質的名詞是學㚙化學 物質的工具。中文化學物質的名詞是中國人民學 習化學物買的工具。中文化學物質名詞要能战媱 中國人民祭習化學物賀的传良工具，就必須不脫 


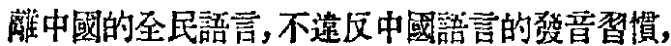
不㩧亂中國語言音義的固有聯繫。而它格身還應 當衤量的简單，便利，而有系統。選樣才能幫助中 國人民記憶和學劦化學物質。所以根據中國的全

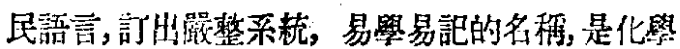
物質中文命名的糸展方向。

幾十年來，中文化學物筫的命名一通是㧓着

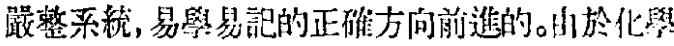

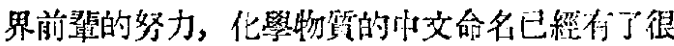
大的成就，集立了良好的根基。二十五年前，营和䣄

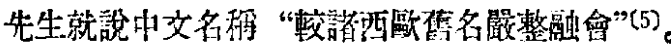
經過二十五年的繼續努力, 今天, 化學物犋的中交

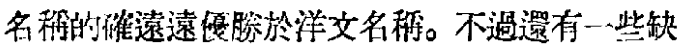
點,需装修正，有些不够奎面的地方，需要補流。言皆 如:元素中的同夏名稱應予修正; 化合物的系統名

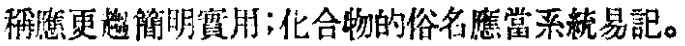
迩些工作决不是少數人所能做得好的。希紫中國 的語言學家和全䯣同志拹同化學界的同志，將化 學物翼的中文命名工作，在已有的基礎上向前推 進！齐垶能在最近一兩年內完成化學物質的中文
命名工作！希空化學物質的中文名秎能成陑世界 上最嚴整,最系統，最容易記憶和學㕷的名詞!

〔註〕Mroma 先生在新文字牛月刊76期第9面上 說:“吸收外國的名詞亚不是原封不動的搬過来,必須根 港下面的方法中国化一下:

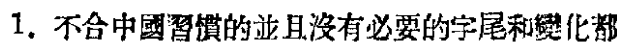
不要。

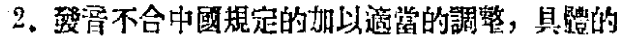
說, 主要的是:

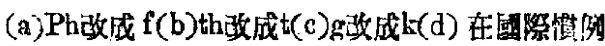

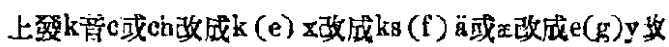

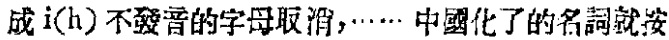
照前面所列的、中國自己的念法發吾，不要按照英文的 念泆登置。…...”

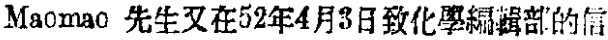
上境:“第一、我們吸收外來語可以有㒳调方式，一個是 按語富吸收，一倜是按寫法吸收，化學名詞出於其特殊

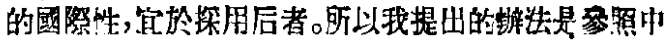

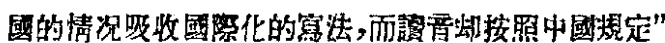

所以可以說 Naomao 先生是“按英交字形租了改 動或不子改動地拼窎成了拉丁化了的中交化學名制”。

\section{引用交 橾}

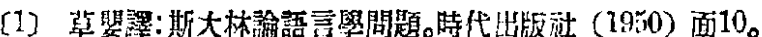

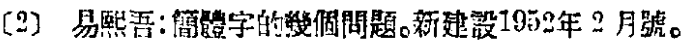

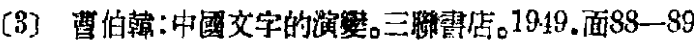

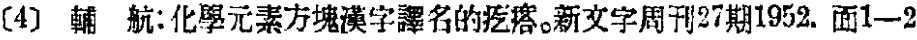

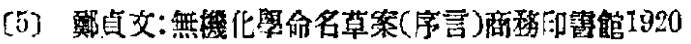

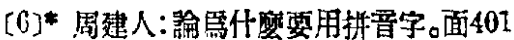

[7]*周建人:談栟視字。面403

[8]*周建人: 論拼㱏交宇的急得提倡。面404

[9]* 品叔湘: 漢字和拼百字的比較。面203

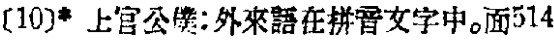

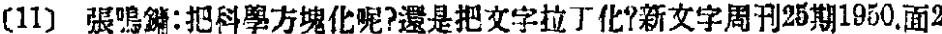

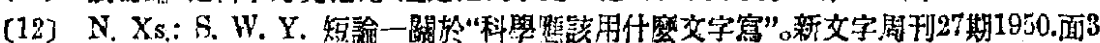

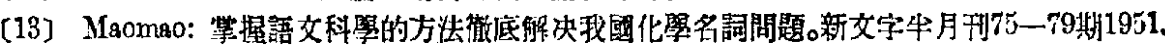

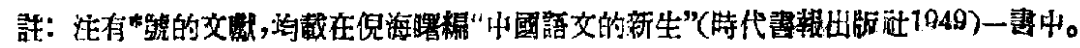

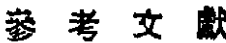

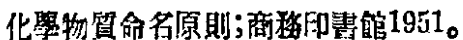

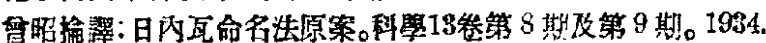

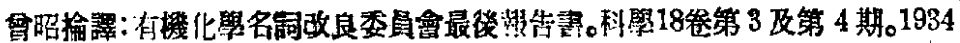
Rules for Naning Inorganic Compourds. J. Am. Chem. Soc. 63, 889-897 (1941) 北京大學緊學院生物化學科:生物化盿名詞草策。 中国生物化悬會上海分會:生物化學名詞草策。

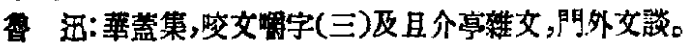

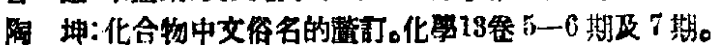

